\title{
Direcionadores estratégicos de TI
}

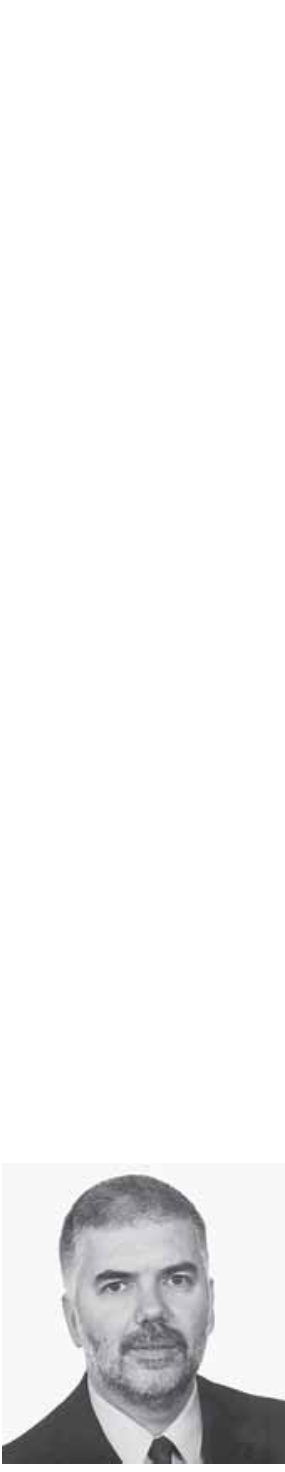

Alberto Luiz Albertin FGVEAESP

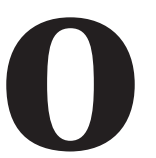

uso de Tecnologia de Informação

(TI) nas empresas deve atender ao propósito de suprir as necessidades estratégicas e operacionais da organização, contribuindo para seu bom desempenho final. Todavia, esse uso não pode ser decidido sem se considerar o contexto em que as organizações estão inseridas. N esta coluna, destaco quatro dimensões desse contexto e que agem como direcionadores estratégicos do uso de TI. 0 primeiro desses direcionadores éo de mercado. As estratégias e operações das empresas devem atender às pressões do negócio, oferecendo respostas organizacionais necessárias ao seu sucesso ou, pelo menos, à sobrevivência no novo ambiente empresarial. No entanto, as respostas também mudam o mercado, alterando as pressões, que passam a exigir novas respostas. 0 uso de TI deve ser considerado como parte da resposta das organizações às pressões do mercado. 0 segundo direcionador é aquele relacionado à própria organização. Os modelos de negócio devem ser entendidos como a relação criada entre os ambientes externo e interno da organização, suas estratégias, estrutura e processos, indivíduos e cultura e os processos gerenciais. Estes componentes e sua inter-relação definem como a organização participará do mercado. Considerando que a TI tem uma relação direta com cada um deles, ela sempre será afetada e os afetará com essas mudanças.

0 terceiro direcionador do uso de TI refere-se aos indivíduos, que passam igualmente a ser pressionados para se inserirem no ambiente digital, assim como fazem pressão para que os participantes de seus processos também se insiram, fato que ocorre nos níveis econômico, cultural e social. Com isso, os indivíduos tornam-se mais exigentes em relação ao uso de $\mathrm{TI}$, seja com respeito à intensidade como pela qualidade dessa utilização. Tal situação tende também a influenciar as características dos profissionais, que passam a ter maior proximidade com essa tecnologia que é muito utilizada pelas empresas que os empregarão.

Por fim, o quarto direcionador do uso de TI é a própria TI. 0 mercado, as organizações e os indivíduos exigem que as tecnologias sejam desenvolvidas e utilizadas de modo que resolvam seus problemas e ofereçam a inovação necessária para gerações denovas oportunidades. Ao mesmo tempo, a TI oferta uma grande quantidade de funcionalidade einovações que as organizações e indivíduos podem ou não assimilar, e tanto a assimilação como sua recusa acarretam risco.

Uma das armadilhas que as organizações enfrentam ao utilizar novas tecnologias refere-se ao apego àquilo que é conhecido e tem demonstrado algum nível de sucesso. A experiência da organização com inovações tecnológicas, o nível de conhecimento tecnológico e a situação do mercado, entre outros aspectos, interferem diretamente na capacidade da organização de superar essa armadilha. 